\title{
Gender issues in preservice teachers' training: ICT literacy and online learning
}

\author{
Lina Markauskaite
}

The University of Sydney

\begin{abstract}
Gender differences in self reported ICT experience and ICT literacy among first year graduate trainee teachers were investigated. Using a dynamic model, three main components of aspiring teachers' ICT literacy were covered: (1) present general problem solving and technical ICT capabilities; (2) situational and longitudinal sustainability, and (3) transferability of ICT capabilities into a future professional domain. No significant differences were found between females and males for previous experience with ICT. However, males on average worked with computers significantly more hours per week than females. Significant differences between males and females were observed for technical ICT capabilities, and situational and longitudinal sustainability. Males' scores were higher. In the regression analysis, when the impacts of the background and ICT experience variables were controlled, gender failed to be a significant predictor for sustainability scores. However, it remained a significant predictor for some trainee teachers' scores, related to their technical ICT capabilities. Female and male participation in compulsory online learning activities was also compared. No significant differences were observed.
\end{abstract}

\section{Introduction}

The introduction of information and communication technology (ICT) into the educational sector has created new social stereotypes and gender inequalities. Since the invention of computers, ICT related activities have been viewed as a "male domain" (Brosnan \& Davidson, 1996; Panteli, Stack \& Ramsay, 1999) or "something for boys" (Reinen \& Plomp, 1996). In schools, a computer was associated primarily with programming and logical scientific thinking. Thus, old, stereotypic gender differences in attitudes and achievements that previously existed in mathematics and technological disciplines were extrapolated to the new area of ICT. As several research reviews and meta-analyses have summarised, boys were more interested in ICT than girls, were heavier users of computers, had 
more positive attitudes about computers, and thus outperformed girls in ICT literacy ${ }^{1}$ (Reinen \& Plomp, 1993, 1996, 1997; Volman \& Eck, 2001).

During the last two decades, the role of ICT in education changed radically. New technologies became an indispensable aspect of learning, work and everyday life. A number of researchers argued that computing should no longer be regarded as a male domain (King, Bond \& Blandford, 2002; North \& Noyes, 2002; Whitley, 1997). According to them, canonical gender gaps in the educational sector are disappearing and, probably, do not have any practical importance for the future.

However, a number of recent studies have provided evidence that ICT related differences between females and males lessened mainly in access to ICT, and in basic computer skills (Busch, 1995; Rainer, Laosethakul \& Astone, 2003). Meanwhile, gender inequalities now emerged in new areas of ICT use (Braten \& Stromso, 2004; Colley, 2003; Durndell \& Haag, 2002; Ong \& Lai, in press; Rainer et al., 2003; Schumacher \& Morahan-Martin, 2001; Volman \& Eck, 2001; Volman, Eck, Heemskerk \& Kuiper, 2005). For example, men and boys are more intensive users of the Internet, enjoy more competitive forms of e-learning, and encounter different problems while using ICT, compared with women and girls (Colley, 2003; Copper \& Weaver, 2003; Volman \& Eck, 2001; Volman, Eck, Heemskerk, \& Kuiper, 2005). Moreover, several investigations indicated that gender gaps probably became more latent and more complex (Colley, 2003; Mcllroy, Bunting, Tierney \& Gordon, 2001; Mitra, Lenzmeier, Steffensmeier, Avon, Qu \& Hazen, 2001). While gender differences in ICT related attitudes and cognitions disappeared at scale level, they seem to persist at factor level (McIlroy et al., 2001). In addition, female and male students are likely to be different in terms of the types of computer use rather than in all areas of ICT application (Colley, 2003; Mitra et al., 2001).

ICT related gender inequalities concern not only students, but also educators (Rosen \& Weil, 1995). As research reviews reveal, female teachers tend to be more anxious, less experienced and less confident about their ICT competencies and it is less likely that they will apply computers for various teaching and learning purposes compared with their male colleagues (Shapka \& Ferrari, 2003). The majority of school staff positions that are related to ICT (eg., computer coordinators, teachers of computer literacy) are occupied by males (Reinen \& Plomp, 1993). The way in which

1 "ICT literacy" is used as an umbrella term in this paper. It covers all other similar terms, such as "ICT competence", "computer literacy", "digital literacy", "ICT fluency", "ICT skills", "ICT proficiency", that are used for the description of ICT related knowledge, skills, capabilities, values and other attributes. 
teachers interact with students during ICT related activities contributes implicitly to the impression that boys are inherently better in ICT than girls (Volman \& Eck, 2001).

Researchers have suggested that educators have an important role as models when technology is involved (Shashaani, 1993; Weil, Rosen \& Wugalter, 1990). Negative attitudes by teachers' towards ICT and lack of technical ICT competence could impact negatively on a child's perceptions of ICT and can be predictive of later technological discomfort (Weil et al., 1990). In particular, female and male teachers, by providing different patterns in ICT adoption, might negatively impact a "sex specific socialisation" (Reinen \& Plomp, 1996; Shapka \& Ferrari, 2003; Volman \& Eck, 2001).

ICT related gender inequalities create specific challenges for pre-service teachers' training. Pre-service training programs should consider possible gender differences. They should provide aspiring teachers with versatile, gender inclusive ICT training, that allows females and males to attain equally high levels of ICT literacy.

This paper aims for insights into gender differences amongst aspiring teachers commencing postgraduate, pre-service training. It reports the first research results from a study on trainee teachers' ICT literacy at the University of Sydney. The main research questions of this paper are:

1. Do female and male aspiring teachers have similar background characteristics and ICT related experience at the beginning of their postgraduate, pre-service training?

2. Do female and male students have similar beliefs about their capabilities in the following areas of ICT literacy: (a) present ICT literacy (general cognitive and technical ICT capabilities); (b) sustainability of ICT literacy (coping with ICT problems and self learning of new ICT applications); and (c) transferability of ICT literacy into their future professional domain?

3. Do female and male teachers engage similarly in formal online learning activities?

4. Could existing gender differences in trainee teachers' ICT literacy and online learning, if any, be justified by the inequalities in their background characteristics and ICT related experience?

\section{Research on gender issues in pre-service teachers' training}

Previous research on ICT related gender gaps in pre-service teachers' training can be clustered into three large groups: 1) trainee teachers' attitudes about ICT, which include computer anxiety, technophobia and 
technology acceptance; 2) trainee teachers' ICT literacy, which covers computer self efficacy, skills in applying various software applications and other ICT related cognitions, and 3) e-learning, which includes various aspects of learning with ICT.

The majority of research into pre-service teachers' education investigated computer anxiety. Rosen and Weil (1995) reviewed a number of early studies, conducted in 1985-1990, and concluded that the research conclusions had been conflicting. Two studies found no gender differences, while three others found female trainee teachers to be more anxious than males. The results of more recent studies tend to be more consistent with the former rather than the latter finding. Shapka and Ferrari (2003) did not observe any gender differences in computer related attitudes of aspiring teachers. Yuen and Ma (2002) also found no significant gender differences in undergraduate trainee teachers' attitudes towards computers. However, they observed that linear computer acceptance models for male and female students were different.

Several studies investigated computer self efficacy and actual ICT use of female and male trainee teachers. They came to a variety of conclusions. Yuen and Ma's (2002) study investigated actual usage of ICT and did not find any significant gender differences. Qutami and Abu-Jaber (1997) researched computer self efficacy of undergraduate trainee teachers. They did not find gender inequalities in total computer self efficacy and in advanced computer skills, but they did note significant differences in some specific low level computer skills in favour of males. Shapka and Ferrari (2003) studied several aspects of ICT literacy, including strategies for dealing with challenging and novel computer tasks, proximal and distant self efficacy, and actual performance on a computer task. They did not find any gender differences in self efficacy and actual outcomes from a challenging computer task. However, they observed significant differences in students' choices of strategies when faced with a difficult computer situation. In particular, females were more likely to use the help function than males.

Fewer studies have been done on gender issues in e-learning for preservice teachers' training. Braten and Stromso (2004) investigated Internet based learning activities and text processing strategies in a sample of aspiring teachers. They found significant gender differences in self reported learning patterns. Males indicated higher levels of participation in Internet based communication activities than females. Females reported higher levels of strategy use when learning from conventional texts.

A number of studies investigated trainee teachers' attitudes and abilities to use ICT in their professional domain. For example, researchers examined 
the relations between technical ICT capacities and various aspects of ICT use in their future professional domain (Albion, 2001, 2003; Francis-Pelton \& Pelton, 1996; Hakkarainen, Muukkonen, Lipponen, Ilomaki, Rahikainen \& Lehtinen, 2001), analysed the impact of trainee teachers' professional knowledge and experience on their competence to apply ICT in educational settings (Albion, 2001; Iding, Crosby \& Speitel, 2002; Jones, 2002), and studied trainee teachers' beliefs about the use of technology in their professional domain (Albion, 2001; Kellenberger, 1996; Wang, 2002). However, none of the above studies aimed to examine professional attitudes and capabilities of trainee teachers from gender perspectives.

\section{Method}

\section{Instruments}

Two different methods were employed to assess trainee teachers' ICT literacy and their engagement in online learning, a questionnaire based survey, and a quantitative analysis of students' contributions to compulsory online learning activities.

The study of trainee teachers' ICT literacy was based on a dynamic model of ICT literacy comprising of three groups of interacting capabilities: 1) present capacities of ICT literacy; 2) sustainability of ICT capacities and 3) transferability of these capacities into the future professional domain (Markauskaite, 2005; Markauskaite, Reimann, Reid \& Goodwin, 2006) (Figure 1).

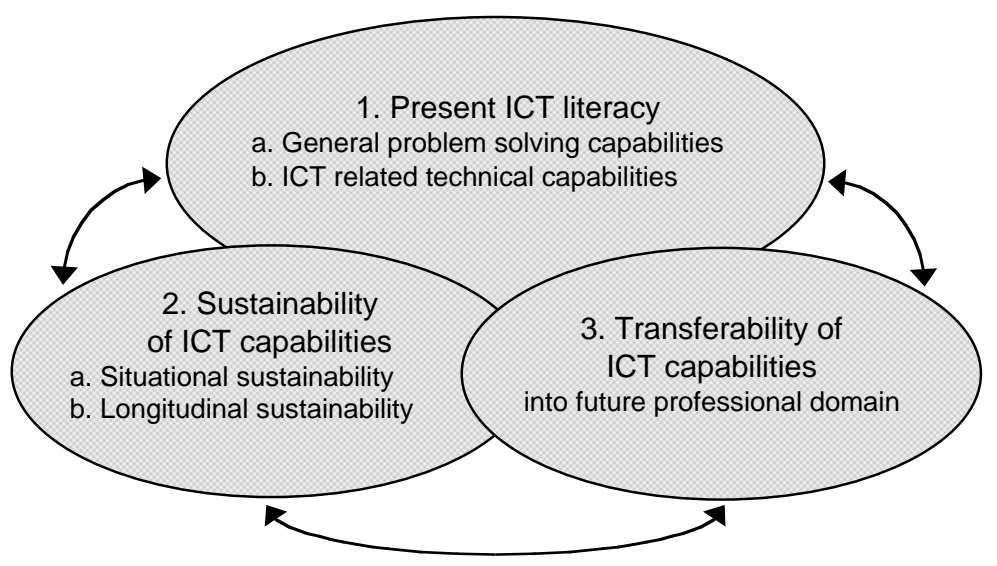

Figure 1: Dynamic model of ICT literacy (after Markauskaite, 2005) 
The structure of the present ICT literacy capacities is based on a "blended" approach to ICT literacy, which includes general cognitive and technical ICT capabilities (Candy, 2004; ETS, 2002). The sustainability of ICT capacities is also composed from two components: situational and longitudinal sustainability. Situational sustainability is defined as a capability to cope with ICT stress in a problem focussed manner (Kohn, 1996; Ropp, 1999). Longitudinal sustainability is defined as a capability to learn new ICT applications independently (Compeau \& Higgins, 1995).

Table 1: Summary of the information about the research instrument

\begin{tabular}{|c|c|c|}
\hline Measurement & $\begin{array}{l}\text { Main } \\
\text { theory }\end{array}$ & Instrument, scales (number of items) \\
\hline \multicolumn{3}{|l|}{ Background } \\
\hline 1. General information & NA & New, nominal and ordinal scales (6) \\
\hline 2. Experience with ICT & NA & New, nominal and ordinal scales (13) \\
\hline \multicolumn{3}{|c|}{ I. Present level of ICT literacy capacities } \\
\hline $\begin{array}{l}\text { 3. General cognitive } \\
\text { capabilities }\end{array}$ & TSSE & $\begin{array}{l}\text { New, items based on AECT (2001), USyd } \\
(1997,2004) \text {, six point Likert scale* }(10)\end{array}$ \\
\hline 4. ICT technical capabilities & TSSE & 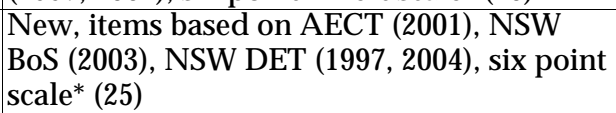 \\
\hline \multicolumn{3}{|l|}{ II. Sustainability of ICT capacities } \\
\hline $\begin{array}{l}\text { 5. Situational sustainability: } \\
\text { ICT coping strategies }\end{array}$ & TPB & $\begin{array}{l}\text { Partly based on Ropp (1999), five point } \\
\text { Likert scale }^{* *}(10)\end{array}$ \\
\hline $\begin{array}{l}\text { 6. Longitudinal sustainability: } \\
\text { Beliefs about self learning to } \\
\text { use ICT }\end{array}$ & GSE & $\begin{array}{l}\text { Based on Compeau and Higgins (1995), six } \\
\text { point Likert scale* }(10)\end{array}$ \\
\hline \multicolumn{3}{|l|}{ III. Transferability of ICT capacities } \\
\hline $\begin{array}{l}\text { 7. Beliefs about the use of ICT } \\
\text { in future career }\end{array}$ & TPB & $\begin{array}{l}\text { New, partly based on Benson, Farnsworth, } \\
\text { Bahr, Lewis and Shaha (2004), Lewis (2003), } \\
\text { Pelgrum and Anderson (2001), Wang (2002), } \\
\text { five point Likert scale** (34) }\end{array}$ \\
\hline \multicolumn{3}{|c|}{$\begin{array}{l}\text { Notes } \\
\text { * Six point Likert scale (0-5): } 0 \text { - Couldn't do that; } 1 \text { - Not at all confident; } 2 \text { - Not } \\
\text { very confident; } 3 \text { - Moderately confident; } 4 \text { - Quite confident; } 5 \text { - Totally confident. } \\
\text { ** Five point Likert scale (0-4): } 0 \text { - Very unlikely; } 1 \text { - Unlikely; } 2 \text { - Possible; } 3 \text { - Likely; } \\
4 \text { - Very likely. }\end{array}$} \\
\hline
\end{tabular}

The study was based on a self assessment research methodology. The questionnaire combined multiple measurement tools and included seven parts. Two parts measured students' background characteristics and ICT related experience, and five parts measured different aspects of ICT literacy (Table 1). Theories of planned behaviour (TPB) (Ajzen, 1991), task specific self efficacy (TSSE) (Agarwal, Sambamurthy \& Stair, 2000; Marakas, Yi \& Johnson, 1998) and general self efficacy (GSE) (Bandura, 1993; Compeau \& Higgins, 1995) were employed for the investigation of constructs. The GSE 
and TTSE were used for those constructs that were largely related to cognitive capabilities to perform various tasks. The TPB was applied for those constructs that concerned not only capabilities, but also an individual's beliefs about the appropriateness of a given behaviour. Some measurements were based on already validated instruments, others were newly developed (Table 1). To achieve consistency, all instruments were adapted to the theory of either self efficacy or the TPB and, respectively, to six or five point Likert scales.

Students' contributions to online learning discussions, which were a part of the compulsory pre-service teachers' training curricula, were used for the evaluation of trainee teachers' engagement in online learning. Throughout the first semester, online data was automatically recorded. Students' engagement in online learning was studied using key social network parameters adapted for the analysis of computer mediated learning.

\section{Subjects and procedure}

The participants were the first year Master of Teaching program students at the University of Sydney. Two hundred and seventeen students were enrolled in the program: $151(69.6 \%)$ were females and $66(30.4 \%)$ were males. The questionnaires were prepared and made available in two forms: printed and online. Invitations to participate in the study were distributed to all students during the first day of the semester. Participation was voluntary. Students were asked to complete either the online or printed versions of the questionnaire within a two week period at any time convenient to them.

One hundred and twenty two students $(56.2 \%)$ volunteered to participate in the survey: $96(78.7 \%)$ females and $26(21.3 \%)$ males. The sample was quite homogenous - every respondent had a bachelor's degree $(4.9 \% \mathrm{had}$ also a master's degree); the average age was 29.6 (standard deviation 8.9) years. More than one-fifth of students $(22.1 \%)$ had a previous degree in science or engineering; others had degrees in various areas of arts and/or human sciences. There were no significant differences between female and male students' background characteristics.

During the first semester, students used ICT in the course "Introduction to Teaching and Learning". Each week, prior to the lecture, each preservice teacher was required to do weekly readings and contribute to a group discussion forum. To access gender differences in students' engagement in online learning, key quantitative parameters about female and male students' participation in online discussions were examined. Only those students who completed the survey were included in the analysis. 


\section{Results}

Analysis of the data was accomplished in four steps. In the first step, ICT related background characteristics and previous experience with ICT of female and male trainee teachers were compared. A chi-square test (for dichotomous variables) and an independent pair t-test (for ordinal and scale variables) were used for the detection of gender differences.

In the second step, various aspects of students' ICT literacy were examined. Initially, females' and males' scores on each individual item were compared. Then, the total scale scores for each of five groups of ICT capabilities were examined. Next, using exploratory principal components' analysis and alpha reliability analysis, the main subgroups of ICT capabilities (ie., factors) were determined. The subgroup scores for females and males were then compared again.

Similarly, students' engagement in online learning was assessed. Four quantitative indicators were used for the comparison of females' and males' engagement in online learning: 1) number of contributions (postings and replies); 2) total length of contributions (words); 3) average length of a contribution; and 4) reply to posting (RTP) index.

In the final step, the significant differences between females and males total and subgroup scores were analysed. It aimed to determine whether gender differences appeared exclusively due to the sexual category or, possibly, because of differences in students' backgrounds and previous experience with ICT. Hierarchical multiple regression was employed for this purpose. The main results of this analysis are reported here.

\section{Students' background and experience with ICT}

General characteristics and previous experience with ICT of female and male students were quite similar (Table 2 and 3). On average, the students used computers for more than 15 years and the Internet for more than 8 years. Just more than half $(50.8 \%)$ of students had been taught to use ICT in a secondary school (grades 7-12) or/and later during the last four years at a university; $61.5 \%$ of them had used ICT for learning various non-ICT subjects in a secondary school (grades 7-12) or/and during the last four years at a university. Many females and males (87.7\%) indicated that they learned the most about computers at work and/or were self taught with or without someone's help. There were no differences between females and males. However, significantly more males $(\mathrm{M})$ than females $(\mathrm{F})$ indicated that they learned the most about computers without any help from others $(\mathrm{F}, 31.3 \% ; \mathrm{M}, 53.8 \%$; chi squared $(1)=4.53, \mathrm{p}<0.01)$. 
Table 2: Students experience with ICT - means

\begin{tabular}{|l|c|c|c|c|c|c|c|c|c|c|}
\hline \multirow{2}{*}{ Indicator } & \multicolumn{3}{|c|}{ Total sample } & \multicolumn{3}{c|}{ Females } & \multicolumn{3}{c|}{ Males } \\
\cline { 2 - 11 } & $\mathrm{N}$ & $\mathrm{M}$ & $\mathrm{SD}$ & $\mathrm{N}$ & $\mathrm{M}$ & $\mathrm{SD}$ & $\mathrm{N}$ & $\mathrm{M}$ & $\mathrm{SD}$ & Signif. \\
\hline $\begin{array}{l}\text { Years since first use of } \\
\text { a computer }\end{array}$ & 121 & 15.6 & 4.3 & 95 & 15.3 & 4.2 & 26 & 16.5 & 4.7 & NS \\
\hline $\begin{array}{l}\text { Years since first use of } \\
\text { the Internet }\end{array}$ & 119 & 8.5 & 2.9 & 94 & 8.3 & 3.0 & 25 & 9.1 & 2.4 & NS \\
$\begin{array}{l}\text { Time of computer use } \\
\text { per week (hrs) }\end{array}$ & 121 & 14.8 & 11.8 & 95 & 13.2 & 9.8 & 26 & 20.4 & 16.2 & $* *$ \\
\hline $\begin{array}{l}\text { Computer time } \\
\text { allocated for learning } \\
(\%)\end{array}$ & 121 & 44.6 & 28.9 & 95 & 44.6 & 28.9 & 26 & 44.6 & 29.6 & NS \\
\hline
\end{tabular}

Notes: N - number of respondents; M - Mean; SD - Standard Deviation; NS - Not Significant; ${ }^{* *}-\mathrm{p}<0.01$.

Table 3: Students experience with ICT - frequencies

\begin{tabular}{|l|c|c|c|c|c|c|c|}
\hline \multicolumn{1}{|c|}{ Indicator } & \multicolumn{2}{|c|}{ Total sample } & \multicolumn{2}{|c|}{ Females } & \multicolumn{2}{c|}{ Males } & Signif. \\
\cline { 2 - 9 } & $\mathrm{N}=122$ & $\%$ & $\mathrm{~N}=96$ & $\%$ & $\mathrm{~N}=26$ & $\%$ & NS \\
\hline $\begin{array}{l}\text { Have access to a computer for off } \\
\text { campus study }\end{array}$ & 114 & 93.4 & 90 & 93.4 & 24 & 92.3 & NS \\
\hline $\begin{array}{l}\text { Have access to the Internet for off } \\
\text { campus study }\end{array}$ & 108 & 88.5 & 85 & 88.5 & 23 & 88.5 & NS \\
\hline $\begin{array}{l}\text { Have been taught to use computers } \\
\text { Used computers for learning }\end{array}$ & 75 & 50.8 & 49 & 51.0 & 13 & 50.0 & NS \\
\hline $\begin{array}{l}\text { Larious subjects } \\
\text { Learned the most about computers } \\
\text { at work or and were self taught } \\
\text { with or without help }\end{array}$ & 107 & 87.7 & 83 & 86.5 & 24 & 92.3 & NS \\
\hline $\begin{array}{l}\text { Learned the most about computers } \\
\text { without help }\end{array}$ & 44 & 36.1 & 30 & 31.3 & 14 & 53.8 & $*$ \\
\hline
\end{tabular}

Notes: N - number of respondents; M - Mean; SD - Standard Deviation; NS - Not

Significant; ${ }^{*}-\mathrm{p}<0.05$.

The majority of participants (93.4\%) had easy access to a computer off campus; $88.8 \%$ of them also had access to the Internet. There were no gender differences. However, on average, male students used computers significantly more hours per week than females (F, 13.2 (9.8); M, 20.4 (16.2), $\mathrm{t}=10.73, \mathrm{~N}=119, \mathrm{p}<0.01)$. On average, both genders allocated for learning activities about a half of their computer time, $44.6 \%(28.9)$.

\section{Students' ICT literacy}

Present ICT literacy

Overall, the students were between "Moderately confident" (3) and "Quite confident" (4) about their general cognitive capabilities. Males were significantly more confident about two specific capabilities: to outline a 
plan $(\mathrm{F}, 2.98(1.11) ; \mathrm{M}, 3.54(0.91) ; \mathrm{t}=2.37, \mathrm{~N}=120, \mathrm{p}<0.05)$ and to find information and select appropriate tools for the solution of a problem $(\mathrm{F}$, 3.31 (0.98); M, 3.73 (0.83); $\mathrm{t}=2.00, \mathrm{~N}=120, \mathrm{p}<0.05)$. Meanwhile, both genders were similarly confident about other general cognitive capabilities, such as to manage, integrate and evaluate information, produce and convey a solution, judge the final product and reflect problem solving processes. The average score over all scales was $3.52(0.66)$ and there were no significant gender differences. The subgroup scores for females and males were also similar (Table 4).

Table 4: Total and subgroup scores of trainee teachers' ICT literacy

\begin{tabular}{|c|c|c|c|c|c|c|c|c|c|c|}
\hline & Tot & al san & nple & & emal & & & Males & & \\
\hline & $\mathrm{N}$ & $\mathrm{M}$ & SD & $\mathrm{N}$ & M & SD & $\mathrm{N}$ & $\mathrm{M}$ & $\mathrm{SD}$ & $\mathrm{SI}$ \\
\hline 1AV: General cognitive capabilities & 120 & 3.52 & 0.67 & 94 & 3.47 & 0.67 & 26 & 3.72 & 0.64 & NS \\
\hline 1F1: Problem solution & 120 & 3.43 & 0.77 & 94 & 3.36 & 0.79 & 26 & 3.69 & 0.65 & NS \\
\hline $\begin{array}{l}\text { 1F2: Communication and } \\
\text { metacognition }\end{array}$ & 120 & 3.66 & 0.66 & 94 & 3.63 & 0.64 & 26 & 3.76 & 0.75 & NS \\
\hline 2AV: ICT capabilities & 120 & 3.03 & 1.01 & 95 & 2.87 & 0.97 & 25 & 3.64 & 0.93 & $* * *$ \\
\hline 2F1: Basic ICT capabilities & 120 & 4.13 & 0.85 & 95 & 4.00 & 0.88 & 25 & 4.62 & 0.47 & $* * *$ \\
\hline $\begin{array}{l}\text { 2F2: Analysis and production } \\
\text { capabilities }\end{array}$ & 120 & 2.70 & 1.27 & 95 & 2.56 & 1.27 & 25 & 3.25 & 1.10 & * \\
\hline $\begin{array}{l}\text { 2F3: Information and Internet } \\
\text { capabilities }\end{array}$ & 120 & 2.63 & 1.13 & 95 & 2.46 & 1.06 & 25 & 3.30 & 1.17 & **** \\
\hline $3 A V$ : ICT coping strategies & 118 & 2.59 & 0.54 & 93 & 2.54 & 0.50 & 25 & 2.81 & 0.63 & $*$ \\
\hline $\begin{array}{l}\text { 3F1: Independent or ICT support } \\
\text { based coping }\end{array}$ & 118 & 2.57 & 0.74 & 93 & 2.47 & 0.73 & 25 & 2.93 & 0.69 & ** \\
\hline $\begin{array}{l}\text { 3F2: Human support based } \\
\text { coping }\end{array}$ & 118 & 3.06 & 0.74 & 93 & 3.08 & 0.73 & 25 & 2.99 & 0.81 & NS \\
\hline $4 A V$ : Self learning to use ICT & 119 & 3.37 & 0.80 & 94 & 3.28 & 0.77 & 25 & 3.70 & 0.86 & * \\
\hline 4F1: Self based learning & 119 & 2.48 & 1.17 & 94 & 2.36 & 1.12 & 25 & 2.92 & 1.26 & * \\
\hline $\begin{array}{l}\text { 4F2: Experience or ICT support } \\
\text { based learning }\end{array}$ & 119 & 3.46 & 0.88 & 94 & 3.35 & 0.83 & 25 & 3.84 & 0.98 & * \\
\hline $\begin{array}{l}\text { 4F3: Human support based } \\
\text { learning }\end{array}$ & 119 & 3.73 & 0.73 & 94 & 3.68 & 0.71 & 25 & 3.94 & 0.76 & NS \\
\hline 5AV: ICT use in future career & 118 & 2.60 & 0.59 & 93 & 2.58 & 0.56 & 25 & 2.68 & 0.68 & NS \\
\hline $\begin{array}{l}\text { 5F1: Enrichment of teaching and } \\
\text { learning }\end{array}$ & 118 & 2.84 & 0.72 & 93 & 2.85 & 0.72 & 25 & 2.82 & 0.75 & NS \\
\hline $\begin{array}{l}\text { 5F2: Communication and self } \\
\text { based learning }\end{array}$ & 118 & 2.43 & 0.73 & 93 & 2.38 & 0.70 & 25 & 2.60 & 0.84 & NS \\
\hline 5F3: Constructivist learning & 118 & 2.31 & 0.70 & 93 & 2.26 & 0.69 & 25 & 2.46 & 0.75 & NS \\
\hline $\begin{array}{l}\text { 5F4: Teaching of general } \\
\text { cognitive capabilities }\end{array}$ & 118 & 3.00 & 0.72 & 93 & 2.97 & 0.75 & 25 & 3.10 & 0.64 & NS \\
\hline 5F5: Teaching of ICT capabilities & 118 & 2.47 & 0.80 & 93 & 2.44 & 0.81 & 25 & 2.61 & 0.78 & NS \\
\hline $\begin{array}{l}\text { 5F6: Professional activities and } \\
\text { development }\end{array}$ & 116 & 2.96 & 0.66 & 92 & 2.98 & 0.63 & 24 & 2.87 & 0.79 & NS \\
\hline
\end{tabular}


Overall, the trainee teachers were between "Not very confident" (2) and more than "Quite confident" (3) about their capabilities to perform various tasks with ICT, such as use general computer and network tools, design text, manage data, create images, presentations and webpages. Males' scores were significantly higher $(p<0.05)$ than females' scores on 20 items out of 25. The largest differences between genders were related to the following capabilities: maintain a computer; manage simple data using spreadsheets; edit and design graphics; create basic and multi-page websites; use personal management tools; deliver the results using presentation tools and networks. The insignificant differences were mainly related to the basic ICT skills, such as: to operate a computer and software; create simple images; search and gather information, and communicate via email. The average scale score was also significantly higher for males than for females (F, 2.87 (0.97); M, 3.64 (0.93); $t=3.51, \mathrm{~N}=120, \mathrm{p}<0.001)$. Males' scores were significantly higher $(\mathrm{p}<0.05)$ than females' scores in all subgroups of technical ICT capabilities.

\section{Sustainability of ICT literacy}

Overall, trainee teachers' intentions towards applying various strategies for coping with ICT problems ranged from just more than "Unlikely" (1) to almost "Very likely" (4). Males were more likely than females to apply only two strategies: browse the available menus (F, $3.13(1.00) ; \mathrm{M}, 3.68(0.48) ; \mathrm{t}=$ $2.56, \mathrm{~N}=118, \mathrm{p}<0.05)$ and visit a website for the users of software and/or hardware (F, 1.71 (1.14); M, 2.52 (1.05); $\mathrm{t}=3.21, \mathrm{~N}=118, \mathrm{p}<0.01)$. Both genders were equally likely to apply all other strategies. The total score on situational sustainability was significantly higher for males than for females (F, 2.54 (0.50); M, 2.81 (0.63); $\mathrm{t}=2.32, \mathrm{~N}=118, \mathrm{p}<0.05)$. In the subgroup "Independent or ICT support based coping", the subscore for males was also significantly higher than for females (F, 2.47 (0.73); M, 2.93 (0.69); $\mathrm{t}=2.81, \mathrm{~N}=116, \mathrm{p}<0.01)$. However, the there was no gender difference in the subgroup "Human support-based coping".

The students were between more than "Not very confident" (2) and just above "Quite confident" (4) about their capabilities to learn new software and/or hardware applications independently under a variety of conditions, such as: without any help; with various kinds of human support, or with ICT help tools. Males were significantly more confident about their capabilities to learn new ICT applications in three situations: even if there was no one around to tell what to do (F, 2.49 (1.16); M, 3.08 $(1.29) ; \mathrm{t}=2.21, \mathrm{~N}=119, \mathrm{p}<0.05)$; if they had a lot of time for that $(\mathrm{F}, 3.51$ (0.89); M, $4.08(1.04) ; \mathrm{t}=2.74, \mathrm{~N}=119, \mathrm{p}<0.01)$ and if they had used similar software before to do the same job (F, $3.94(0.81) ; \mathrm{M}, 4.36(0.70) ; \mathrm{t}=2.38, \mathrm{~N}=$ $119, \mathrm{p}<0.05)$. The students were equally confident about their capabilities for learning new applications under other conditions. The average scale 
score was $3.37(0.80)$ and it was significantly higher for males than for females (F, 3.28 (0.77); M, 3.70 (0.86); $t=2.32, N=119, \mathrm{p}<0.05)$. Males' confidence was also significantly higher in all subgroups of self learning capabilities, with the exception of human support based learning.

Transferability of ICT literacy

Trainee teachers' intentions to apply ICT for various teaching, learning, administration and professional development purposes ranged from just more than "Unlikely" (1) to "Likely" (3). In general, at this initial stage of pre-service training, the majority of students did not have strong views about the use of ICT in their future jobs. Thus, the mode answer to 17 items out of 34 was "Possible". There were almost no significant gender differences. Thirty-three scores out of 34 were similar for both genders. Male students however were more likely to design assignments in which students will need to make presentations with ICT (F, 2.38 (0.91); M, 2.80 $(0.94) ; \mathrm{t}=2.01, \mathrm{~N}=118, \mathrm{p}<0.05)$. The average score for all items was 2.60 (0.59) and there was no significant gender difference. Students' scores were also similar in all subgroups.

\section{Students' participation in online learning}

During the first semester, all 119 students $^{2}$ made 2488 contributions (745105 words) to online discussions on weekly readings (Table 5). On average each student made 20.9 (10.29) contributions and wrote 6261 (2042) words. The average length of contributions was 306 (88.6) words, and reply to posting index was $0.38(0.361)$. Male students made more contributions and wrote, on average, messages 30 words longer than female students did. The total length of all contributions and RTP index were also higher for male students than for females. All these differences, however, were relatively small and statistically insignificant.

Table 5: Main quantitative indicators about students' participation in online learning

\begin{tabular}{|l|c|c|c|c|c|c|c|c|c|c|}
\hline & \multicolumn{2}{|c|}{ Total sample } & \multicolumn{3}{c|}{ Females } & \multicolumn{3}{c|}{ Males } \\
\cline { 2 - 11 } & N & M & SD & N & M & SD & N & M & SD & \\
\hline Number of contributions & 119 & 20.9 & 10.29 & 93 & 20.9 & 11.08 & 26 & 21.12 & 7.01 & NS \\
\hline Number of words & 119 & 6261 & 2842 & 93 & 6107 & 2856 & 26 & 6814 & 2776 & NS \\
\hline $\begin{array}{l}\text { Average length of a } \\
\text { contribution }\end{array}$ & 199 & 306 & 88.6 & 93 & 300 & 80.7 & 26 & 330 & 111.3 & NS \\
\hline Reply to posting index & 119 & 0.38 & 0.361 & 93 & 0.37 & 0.374 & 26 & 0.39 & 0.318 & NS \\
\hline
\end{tabular}

Notes: N - Number of respondents; M - Mean; SD - Standard Deviation; NS - Not significant.

\footnotetext{
${ }^{2}$ Three female students did not indicate their student identification numbers in the survey questionnaire and it was impossible to identify their contributions to online discussions. Therefore, only 119 students were included in this analysis.
} 


\section{Regression analysis of significant gender differences}

The significant gender differences in students' ICT literacy were investigated further using hierarchical multiple regression. Three total and six subgroup scores were used as dependent variables in the regression analysis: 2AV; 2F1; 2F2; 2F3; 3AV; 3F1; 4AV; 4F1 and 4F2. On the basis of the literature review, the following background and ICT experience indicators were selected as potential predictors of ICT literacy scores: 1) age (AG); 2) years since the first computer use (YR); 3) easy access to a computer at the place of off campus study (AC); 4) hours of computer use per week (HR); 5) previous degree in science (DG); 6) previous learning to use ICT (PL); 7) previous use of ICT for learning various non-ICT subjects (PU); 8) experience of learning about computers independently with or/and without support from others or/and at work (LH);9) experience of learning about computers autonomously without support from others (LA). The significances of the relationships between the background indicators and students' total and subgroup scores of ICT literacy were investigated using t-test (for dichotomous variables) and correlation analysis (for ordinal variables). Two ordinal and four dichotomous variables had significant relationships ( $p<0.05)$ : YR; HR; DG; PL; PU and LA. These indicators and gender (GN) were selected as independent variables for the factor analysis.

Initially, the six variables (YR, HR, DG, PL, PU and LA) were entered into regression analysis together in the first step, whereas gender (GN) was entered separately in the second step. The regression coefficients of PU, PL and LA were insignificant for all nine students' scores. Therefore, these indicators were removed from the regression and the analysis was repeated again with only three independent variables (YR, HR and DG) in the first step and gender $(\mathrm{GN})$ in the second. Table 6 shows the summary of the results.

At the first step obtained regressions explained from $10 \%$ to $24 \%$ of variances in the students' scores and always were statistically significant. Gender, entered at the second step, explained further from $1 \%$ to $4 \%$ of variances. For the six scores, gender did not explain a significant increment in proportion to the variances explained by other background variables. However, the changes in variances were statistically significant $(p<0.05)$ for the following three scores: 1) Total technical ICT capabilities (2AV); 2 ) Basic ICT capabilities (2F1) and 3) Information and Internet-related capabilities (2F3). 
Table 6: Summary of the results of hierarchical regression

\begin{tabular}{|c|c|c|c|c|c|c|c|c|c|}
\hline & $\begin{array}{c}\text { I step (DG, YR, } \\
\text { HR) }\end{array}$ & \multicolumn{3}{|c|}{ II step (GN) } & \multicolumn{3}{c|}{ Standardised beta coefficients } \\
\cline { 2 - 10 } & $\mathrm{R}^{2}$ & $\begin{array}{c}\mathrm{F} \\
(3,110)\end{array}$ & $\mathrm{R}^{2}$ & $\mathrm{R}^{2} \mathrm{Ch}$ & $\begin{array}{c}\mathrm{F} \text { Ch } \\
(1,109)\end{array}$ & DG & YR & HR & GN \\
\hline 2AV & 0.22 & $10.62^{* * *}$ & 0.26 & 0.04 & $5.93^{*}$ & $0.24^{* * *}$ & 0.13 & $0.28^{* * *}$ & $0.21^{* *}$ \\
\hline 2F1 & 0.20 & $9.23^{* * *}$ & 0.24 & 0.04 & $5.38^{*}$ & 0.15 & $0.25^{* * *}$ & $0.24^{* *}$ & $0.20^{*}$ \\
\hline 2F2 & 0.19 & $8.52^{* * *}$ & 0.20 & 0.02 & 2.42 & $0.26^{* * *}$ & 0.11 & $0.25^{* *}$ & 0.14 \\
\hline 2F3 & 0.20 & $8.99^{* * *}$ & 0.24 & 0.04 & $5.93^{* *}$ & $0.22^{* *}$ & 0.07 & $0.29^{* * *}$ & $0.21^{*}$ \\
\hline 3AV & 0.10 & $4.03^{* * *}$ & 0.12 & 0.02 & 2.38 & -0.06 & $0.22^{*}$ & 0.16 & 0.14 \\
\hline 3F1 & 0.13 & $5.53^{* * *}$ & 0.16 & 0.03 & 3.73 & -0.02 & $0.20^{* *}$ & $0.23^{* * *}$ & 0.18 \\
\hline 4AV & 0.23 & $10.79^{* * *}$ & 0.23 & 0.01 & 1.01 & $0.17^{*}$ & $0.24^{* *}$ & $0.31^{* * *}$ & 0.09 \\
\hline 4F1 & 0.24 & $11.29^{* * *}$ & 0.24 & 0.00 & 0.66 & 0.15 & $0.27^{* * *}$ & $0.32^{* * *}$ & 0.07 \\
\hline 4F2 & 0.20 & $9.11^{* *}$ & 0.21 & 0.01 & 1.94 & $0.19^{* *}$ & $0.20^{*}$ & $0.28^{* * *}$ & 0.12 \\
\hline
\end{tabular}

The average time of computer use per week (HR) was a significant positive predictor of students' scores in the eight out of nine regression models. In six cases, it had the highest partial correlation coefficient. The degree in science (DG) was a significant predictor of non-basic technical ICT capabilities. It also explained a significant part of the variance in students' capabilities at learning new software applications independently with various ICT based scaffolders (manuals, online help, etc.). However, the degree in science was not a significant predictor of basic technical ICT capabilities, ICT coping capabilities and self based learning capacities. In contrast, the years of ICT use (YR) was a significant predictor of basic ICT capabilities and all coping and self learning scores, but it was insignificant predictor of advanced ICT scores (i.e., analysis and production capabilities, and information and Internet related capabilities).

\section{Discussion and conclusions}

Almost all new trainee teachers had a substantial experience of ICT use. The majority of females and males had easy access to a computer and Internet outside the university campus. These results are consistent to the findings of many other recent studies (King et al., 2002; North \& Noyes, 2002; Whitley, 1997). They confirm that gender gaps related to ICT access diminished and probably do not have practical importance. Nevertheless, even having similar technical opportunities, female students were significantly less intensive users of ICT than their male classmates.

Female and male trainee teachers had quite similar previous exposure to computers and Internet. About half of them were taught to use ICT in school or at university. Nevertheless, the majority of them were mainly self taught or learned the most about ICT from practical experience at work. 
Female and male trainee teachers have similar self learning experience. However, significantly more males than females learned the most about ICT completely autonomously.

There were many gender differences in students' ICT literacy. Male students were significantly more confident about their capabilities to plan, find information and select ICT tools. However, on the whole, the confidence of female and male trainee teachers about their general cognitive capabilities was quite similar. This result is as expected, given that the researched sample was homogenous in educational background, with students having similar learning experiences and cognitive skills.

In contrast, females' and males' confidence about their technical ICT capabilities was significantly different. Gender gaps were observed in all subgroups of technical ICT capabilities. This finding is different from the results of some other similar studies (Qutami \& Abu-Jaber, 1997; Shapka \& Ferrari, 2003; Yuen \& Ma, 2002). The hierarchical regression analysis showed that higher confidence in performing various analytical and production tasks with ICT was associated with longer hours of computer usage per week and a previous degree in science. Gender, when the influence of the background and ICT experience variables was controlled, was an insignificant predictor of students' scores. Higher students' confidence about their basic ICT skills and their information and Internet related capabilities were associated with longer hours of ICT use per week, longer experience of computer use and/or previous degree in science and gender. In the latter cases, even when the influence of the background and ICT experience variables was controlled, gender was a significant predictor of an additional proportion of the variance. Therefore, the lower females' confidence about these two capabilities cannot be explained by the inequalities in their background characteristics.

Female and male students were equally confident about their capabilities for learning new software and/or hardware applications with human help. However, male students were significantly more confident about their capabilities for mastering new applications autonomously. Nevertheless, when the influence of the background and ICT experience variables was controlled, gender did not explain a significant additional proportion of the variance. Therefore, gender differences in the capabilities for learning about ICT autonomously could be caused by the inequalities in students' background characteristics and ICT experience. The time of computer usage per week and years since the first computer use were significant predictors of all students' longitudinal sustainability scores. Females worked with a computer significantly less time over the course of a week than males did. It is likely that this factor contributed the most to gender differences in students' confidence about their self learning capabilities. 
Similar patterns of gender differences were observed in students' strategies for coping with ICT problems. Females and males were similarly likely to employ various human support based coping strategies. However, males were more likely to cope with ICT related problems autonomously and/or with various ICT based support tools. In the regression analysis, when the impact of the background and ICT experience variables was controlled, gender failed to explain a significant increment. Therefore, the differences between females and males probably appeared because of the inequalities in other students' characteristics rather than gender per se. These findings about students' self learning to use ICT and coping strategies are quite consistent with the results of other research (Reinen \& Plomp, 1996; Shapka \& Ferrari, 2003). Female students prefer cooperative learning situations, thus it is more likely that they will seek for human help. Males however like a competitive learning style, and consequently it is more likely that they will try to find the solutions on their own.

At the beginning of pre-service training, neither female nor male students had strong opinions about the use of ICT in their future careers. They were neutral about applications of ICT in teaching and professional activities.

During the first semester, females and males engagement in formal online learning activities was very similar. Like in some other studies (e.g., Barrett \& Lally, 1999), it was observed that male students sent more messages and wrote longer contributions. Nevertheless, these differences were small and statistically insignificant.

Overall, this study revealed some significant gender differences in trainee teachers' ICT literacy. Gender gaps were observed on both scale and factor levels. The most alarming is the gap between female and male students' confidence about their technical ICT capabilities. The items included in the instrument for the self assessment of technical ICT skills were based on the national and international standards relevant to trainee teachers and school students (ACDE, 1998; NSW BoS, 2003; NSW DET, 1997, 2004). Thus, the scale covered the basic set of technical ICT capabilities that every school teacher is expected to master. The observed gender gaps, if not addressed properly during pre-service training, could later be transferred into the classroom and negatively affect children's learning.

Although it is difficult to detect precisely what causes gender differences, it is likely that one of the most influential factors is the time spent on various computer activities. Pre-service training programs could encourage female students to spend more time with a computer by integrating ICT across pre-service curricula. In addition, pre-service teachers' training could employ various ICT-based cooperative learning approaches that are well suited to female students. In general, pre-service teachers' training should 
focus on enhancement of professional understanding and experience about the use of ICT in teaching and learning, rather than narrowly upon developing technical ICT skills.

This study investigated gender inequalities at the initial phase of preservice teacher training. In the future it will be important to observe what changes trainee teachers experience regarding various aspects of their ICT literacy and engagement in online learning as they proceed further in their postgraduate pre-service training.

\section{References}

ACDE (1998). Preparing a profession. Report of the national standards and guidelines for initial teacher education project. Canberra: Australian Council of Deans of Education. [verified 17 Feb 2006] http:/ / eric.ed.gov/ERICWebPortal/ contentdelivery/servlet/ERICServlet?accno=ED419803

AECT (2001). Standards for the accreditation of programs in educational communications and instructional technology (ECIT) (4 ed.). Bloomington, IN: Association for Educational Communications and Technology.

Agarwal, R., Sambamurthy, V. \& Stair, R. M. (2000). Research report: The evolving relationship between general and specific computer self-efficacy - an empirical assessment. Information Systems Research, 11(4), 418-430.

Ajzen, I. (1991). The theory of planned behavior. Organizational Behavior and Human Decision Processes, 50, 179-211.

Albion, P. R. (2001). Some factors in the development of self-efficacy beliefs for computer use among teacher education students. Journal of Technology and Teacher Education, 9(3), 321-347.

Albion, P. R. (2003). Graduating teachers' dispositions for integrating information and communications technologies into their teaching. In The Society for Information Technology and Teacher Education International Conference. (pp. 15921599). http:/ / dl.aace.org/12009 [viewed 18 Jun 2005].

Bandura, A. (1993). Perceived self-efficacy in cognitive development and functioning. Educational Psychologist, 28(2), 117-148.

Barrett, E. \& Lally, V. (1999). Gender differences in an on-line learning environment. Journal of Computer Assisted Learning, 15, 48-60.

Benson, L. F., Farnsworth, B. J., Bahr, D. L., Lewis, V. K. \& Shaha, S. H. (2004). The impact of training in technology assisted instruction on skills and attitudes of pre-service teachers. Education, 124(4), 649-663.

Braten, I. \& Stromso, H. I. (2004). Epistemological beliefs, interest, and gender as predictors of Internet-based learning activities. Computers in Human Behaviour, article in press.

Brosnan, M. \& Davidson, M. (1996). Psychological gender issues in computing. Journal of Gender, Work and Organization, 3, 13-25.

Busch, T. (1995). Gender differences in self-efficacy and attitudes toward computers. Journal of Educational Computing Research, 12, 147-158. 
Candy, P. C. (2004). Linking thinking. Self-directed learning in the digital age. DEST. http://www.dest.gov.au/sectors/training_skills/publications_resources/ other_publications/linking_thinking.htm

Colley, A. M. (2003). Gender differences in adolescents' perceptions to the best and worst aspects of computing at school. Computers in Human Behavior, 19, 673-682.

Compeau, D. R. \& Higgins, C. A. (1995). Computer self-efficacy: Development of a measure and initial test. MIS Quarterly, 19(2), 189-211.

Copper, J. \& Weaver, K. D. (2003). Gender and computers: Understanding the digital divide. Mahwah, NJ: LEA.

Durndell, A. \& Haag, Z. (2002). Computer self-efficacy, computer anxiety, attitudes towards the Internet and reported experience with the Internet, by gender, in an east European sample. Computers in Human Behavior, 18, 521-535.

ETS (2002). Digital transformation: A framework for ICT literacy. USA: Educational Testing Service.

Francis-Pelton, L. \& Pelton, T. W. (1996). Building attitudes: How a technology course affects preservice teachers attitudes about technology. Technology and Teacher Education Annual. http:/ / web.uvic.ca/ tpelton/attitudesite.htm [viewed 14 Sep 2004, verified 27 Feb 2006].

Hakkarainen, K., Muukkonen, H., Lipponen, L., Ilomaki, L., Rahikainen, M. \& Lehtinen, E. (2001). Teachers' information and communication technology (ICT) skills and practices of using ICT. Journal of Technology and Teacher Education, 9(2), 181-197.

Iding, M., Crosby, M. E. \& Speitel, T. (2002). Teachers and technology: Beliefs and practices. International Journal of Instructional Media, 29(2), 153-170.

Jones, A. (2002). Refusing or Ignoring? An investigation of student teachers perceptions and use of computers. In Untangling the Web: Establishing Learning Links. Proceedings ASET Conference, Melbourne, 7-10 July. http:/ / www.aset.org.au/confs/2002/jones.html [viewed 16 Jun 2005].

Kellenberger, D. (1996). Preservice teachers' perceived computer self-efficacy based on achievement and value beliefs within a motivational framework. Journal of Research on Computing in Education, 29(2), 124-140.

King, J., Bond, T. \& Blandford, S. (2002). An investigation of computer anxiety by gender and grade. Computers in Human Behavior, 18, 69-84.

Kohn, P. M. (1996). On coping adaptively with daily hassles. In M. Zeider \& N. S. Endler (Eds), Handbook of coping (pp. 181-201). New-York: Wiley.

Lewis, V. K. (2003). The use of assessment in improving technology based instruction programs. Journal of Instructional Psychology, June.

Marakas, G. M., Yi, M. \& Johnson, D. (1998). The multilevel and multifaceted character of computer self-efficacy: Toward clarification of the construct and an integrative framework for research. Information Systems Research, 9(2), 26-163.

Markauskaite, L. (2005). From a static to dynamic concept: A model of ICT literacy and an instrument for self-assessment. In P. Goodyear, D. G. Sampson, D. J.-T. Yang, Kinshuk, T. Okamoto, R. Hartley \& N.-S. Chen (Eds), The 5th IEEE International conference on Advanced Learning Technologies. ICALT 2005. Proceedings. Kaohsiung, Taiwan, 5-8 July (pp. 464-466). Los Alamitos, CA: IEEE Computer Society. 
Markauskaite, L., Reimann, P., Reid, D. \& Goodwin, N. (2006). Exploring the fit of an information technology course to the ICT literacy of trainee teachers. Paper presented at the Society for Information Technology and Teacher Education, SITE'2006, 17th International Conference, Orlando, Florida, 20-24 March.

McIlroy, D., Bunting, B., Tierney, K. \& Gordon, M. (2001). The relation of gender and background experience to self-reported computing anxieties and cognitions. Computers in Human Behavior, 17(1), 21-33.

Mitra, A., Lenzmeier, S., Steffensmeier, T., Avon, R., Qu, N. \& Hazen, M. (2001). Gender and computer use in an academic institution: Report from a longitudinal study. Journal of Educational Computing Research, 23(1), 67-84.

North, A. S. \& Noyes, J. M. (2002). Gender influences on children's computer attitudes and cognitions. Computers in Human Behavior, 18, 135-150.

NSW BoS (2003). Trial year 10 computing skills assessment 2003. NSW: Office of the Board of Studies.

NSW DET (1997). Computer proficiency for teachers. Report. NSW: Dept of Education and Training, Ministerial Advisory Council on the Quality of Teaching.

NSW DET (2004). Computing skills assessment. Year 6. School manual of administrative procedures. NSW Department of Education and Training.

Ong, C.-S. \& Lai, J.-Y. (in press). Gender differences in perceptions and relationships among dominants of e-learning acceptance. Computers in Human Behavior.

Panteli, N., Stack, J. \& Ramsay, H. (1999). Gender and professional ethics in the IT industry. Journal of Business Ethics, 22(1), 93-101.

Pelgrum, W. J. \& Anderson, R. E. (Eds) (2001). ICT and the emerging paradigm for life long learning: An IEA educational assessment of infrastructure, goals and practices in twenty-six countries. (2 ed.). The Netherlands: IEA.

Qutami, Y. \& Abu-Jaber, M. (1997). Students' self-efficacy in computer skills as a function of gender and cognitive learning style at Sultan Quaboos University. International Journal of Instructional Media, 27(1), 63-74.

Rainer, R. K., Laosethakul, K. \& Astone, M. K. (2003). Are gender perceptions of computing changing over time? Journal of Computer Information Systems, 43, 108114.

Reinen, I. J. \& Plomp, T. (1993). Gender and computers: Another area of inequality in eduction? In W. Pelgrum, I. J. Reinen \& T. Plomp (Eds), Schools, Teachers, Students and Computers: A Cross-National Perspective. The Hague: IEA.

Reinen, I. J. \& Plomp, T. (1996). Gender and new technology. In T. Plomp \& D. P. Ely (Eds), International Encyclopedia of Educational Technology (pp. 630-635). Cambridge, UK: Pergamon.

Reinen, I. J. \& Plomp, T. (1997). Information technology and gender equality: A contradiction in terms. Computers and Education, 28(2), 65-78.

Ropp, M. M. (1999). Exploring individual characteristics associated with learning to use computers in preservice teacher preparation. Journal of Research on Computing in Education, 31(4), 402-424. 
Rosen, L. D. \& Weil, M. M. (1995). Computer availability, computer experience and technophobia among public school teachers. Computers in Human Behavior, 11(1), 9-31.

Schumacher, P. \& Morahan-Martin, J. (2001). Gender internet and computer attitudes and experiences. Computers in Human Behaviour, 17, 95-110.

Shapka, J. D. \& Ferrari, M. (2003). Computer-related attitudes and actions of teacher candidates. Computers in Human Behaviour, 19(3), 319-334.

Shashaani, L. (1993). Gender-based differences in attitudes toward computers. Computers and Education, 20(2), 169-181.

USyd (1997). Generic attributes of the graduates of the University of Sydney. Sydney: Academic Board of the University of Sydney.

USyd (2004). Information literacy policy statement. Sydney: University of Sydney Library. http://www.usyd.edu.au/skills/infopolicy.html [viewed 1 Nov 2004].

Volman, M. \& van Eck, E. (2001). Gender equality and information technology in education: The second decade. Review of Educational Research, 71(4), 613-634.

Volman, M., van Eck, E. , Heemskerk, I. \& Kuiper, E. (2005). New technologies, new differences. Gender and ethic differences in pupils' use of ICT in primary and secondary education. Computers and Education, 45, 35-55.

Wang, Y.-M. (2002). When technology meets beliefs: Preservice teachers' perception of the teacher's role in the classroom with computers. Journal of Research on Technology in Education, 35(1), 150-161.

Weil, M. M., Rosen, L. D. \& Wugalter, S. (1990). The etiology of computerophobia. Computers in Human Behavior, 6, 361-379.

Whitley, B. (1997). Gender differences in computer related attitudes and behaviour: a meta-analysis. Computers in Human Behaviour, 13, 1-22.

Yuen, A. H. K. \& Ma, W. W. K. (2002). Gender differences in teacher computer acceptance. Journal of Technology and Teacher Education, 10(3), 365-382.

This article received an Outstanding Paper Award at ASCILITE 2004, gaining the additional recognition of publication of an expanded version in AJET. The reference for the Conference version is:

Markauskaite, L. (2005). Exploring differences in trainee teachers' ICT literacy: Does gender matter? In H. Goss (Ed), Balance, fidelity, mobility: Maintaining the momentum? Proceedings of the 22nd ASCILITE Conference (pp. 445-455). Brisbane, 4-7 December. http://www.ascilite.org.au/ conferences/brisbane05/blogs/proceedings/51_Markauskaite.pdf

Lina Markauskaite is a Postdoctoral Fellow at the Centre for Research on Computer Supported Learning and Cognition (CoCo), School of Development and Learning, Faculty of Education and Social Work (A35), University of Sydney, NSW 2006, Australia. http://coco.edfac.usyd.edu.au/ Email: 1.markauskaite@edfac.usyd.edu.au 